\title{
A Nation-wide Survey on Financial Impact of COVID-19 on Employers of Private Dental Practices of Pakistan
}

Huma Sarwar ${ }^{1}$

Navid Rashid Qureshi ${ }^{2}$

Siddiqua Fatima ${ }^{3}$

Meshal M Naeem ${ }^{4}$

Ahsan Inayat ${ }^{5}$

\author{
BDS, MDS \\ BDS, MSc, FDSRCS \\ BDS \\ BDS \\ BDS
}

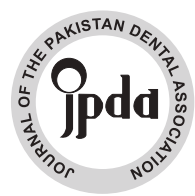

OBJECTIVE: To assess the financial impact of COVID-19 on employers of private dental practices of Pakistan in the month of April and May 2020.

METHODOLOGY: In this cross sectional study, the employers of dental practices of Pakistan were inquired about their financial management during COVID 19 outbreak. The data was analyzed using IBM-SPSS version 23.0. Percentages and Chi-square tests were used for statistical analysis at $\mathrm{p} \leq 0.05$.

RESULTS: $52.7 \%$ owners opened their practices whereas $37.8 \%$ of tenants' clinics remained closed (p<0.01). 38.3\% of tenant employers provided inadequate PPE whereas 53.2\% owners provided adequate PPE to their staff ( $\mathrm{p}=0.02$ ). $64 \%$ of owners easily arranged PPE for staff whereas $70.4 \%$ tenants found it difficult to arrange PPE because of its high cost. Employers with less than 10 years of practice reported less than $5 \%$ whereas those with more than 10 years of practice reported up to $24 \%$ of revenue generation income $(\mathrm{p}<0.01)$. Most of the employers paid full salary to their employees. If this condition persists till the end of August, $40.8 \%$ employers ( $<10$ years practice) planned to adjust staff salaries whereas $33 \%$ employers $(>10$ years of practice) planned to find innovative ways to lower their operating costs $(\mathrm{p}<0.01)$.

CONCLUSION: Due to minimal patient turnover, dental employers are facing incredible challenges in managing the expenses. Those with more than 10 years of practice are more economically stable as compared to the employers with less than 10 years of practice.

KEYWORDS: COVID-19, finances, dental clinic, Pakistan.

HOW TO CITE: Sarwar H, Qureshi NR, Fatima S, Naeem MM, Inayat A. A nation-wide survey on financial impact of COVID-19 on employers of private dental practices of Pakistan. J Pak Dent Assoc 2020;29(4):172-178.

DOI: https://doi.org/10.25301/JPDA.294.172

Received: 26 August 2020, Accepted: 07 September 2020

\section{INTRODUCTION}

$\mathrm{A}$ 11 planning lost their substantiality when nature decided to show its wrath. The novel COVID-19 came under the limelight in December 2019 and was declared pandemic in first week of march by WHO. ${ }^{1}$

The transmission of the said infectious agent, infamously known as COVID-19 was initially baffling even to an astute

1. Lecturer, Department of Operative Dentistry, Dr Irshad-ul-Ebad Khan Institute of Oral Health Sciences, Karachi Pakistan.

2. Principal, Department of Oral and Maxillofacial Surgery, Liaquat College of Medicine and Dentistry, Karachi.

3. MDS (Trainee), Department of Operative Dentistry, Altamash Institute of Dental Medicine.

4. MDS Resident, Lecturer, Department of Periodontology, Dr Ishrat-ul-Ebad Khan Institute of Oral Health Sciences, Karachi Pakistan.

5. MDS Resident, Department of Prosthodontics, Dr Irshad-ul-Ebad Khan Institute of Oral Health Sciences, Karachi.

Corresponding author: "Dr. Huma Sarwar” < huma.sarwar@duhs.edu.pk > mind. The course of occurrences and research suggested that it is caused by a virus and is transmitted rapidly if contaminated hands touch mouth, nose or eyes or via sneeze droplets in the air. This is one of a kind natural bio destruction witnessed by this generation. With over 550,000 confirmed infectious cases globally, and 25,000 reported deaths, this phenomenon has resulted in the unprecedented confinement of thousands of people to the four walls of their dwellings; a lockdown that is caused by nature and not war. ${ }^{2}$ The pandemic is negatively affecting global economic growth beyond anything experienced in nearly a century. In China, the industrial production fell by $13.5 \%$ and numerous economic gurus' predictions surfaced that the US economy could shrink by $24 \% .{ }^{3}$ Current estimates and figures indicate that the virus has trimmed south Asian economic growth by $2.7 \%$. Not a single sector was safe from the economic brutality brought forward by COVID-19. The reported global 
Sarwar H/ Qureshi NR/ Fatima S/ Naeem MM/ Inayat A

spillover of COVID-19 engulfed the travel industry, hospitality industry, sports industry, the financial sector like banks, financial market (stock market), event industry, entertainment industry, education sector, and health sector. ${ }^{4}$ Human imagination is yet to fathom the full impact and extent of the effects of the pandemic peak.

The dental industry was no exception in the ongoing health and economic fiasco; it too faced its fair share of turbulence. The impact of the COVID-19 crisis and lockdowns were significantly visible. Given the fact that many dental procedures result in aerosol production and the dentists have to work close to patients' oral cavity; the dentist community was declared to be extremely vulnerable and prone to infection, as well as transmission of COVID-19.5,6 These risks and circumstances, compelled the health regulatory bodies to advise and limit the dental community to avoid elective dental procedure and to provide emergency treatment only. ${ }^{7,89}$ Unprecedented monetary challenges are being faced by the dental fraternity, as the practices have been limited to the cases pertaining to the dental emergencies only. The dentists of Pakistan can be parted in two main categories. Category 1 entails dentists who are small business employers, operating independently, or rather with a few partners. Category 2 encompasses the dentists who own practices in rental premises and are hence subjected to monthly rent payments (as additional expenses). Furthermore, the financial burden on employers can be divided into four categories; salaries, rent, supplies, and labs.

Due to the COVID-19 pandemic, additional personal protective barrier (PPE) cost has to be borne by the employers. No visible policy to support private dental practices in this difficult time has been put forward by the governments or dental regulatory bodies of low-income and middle-income countries. With expenses of salaries / rent being the same, but diminishing revenues, the stress, and anxiety have significantly increased amongst the dentists throughout the world. ${ }^{10}$ Moreover, there is limited evidence about the economical downfall being faced by the employers of private dental practices of Pakistan. Given the unprecedented circumstances, the decision making is impeded by a lack of data, such as the challenges being faced by the dentists to strive for their professional excellence in this difficult time. Therefore, the objective of this study is to report the issues and economic impact of the COVID-19 outbreak on employers of private dental practices of Pakistan.

\section{METHODOLOGY}

This cross-sectional study was conducted in the private dental clinics of Pakistan. Ethical approval was obtained from the Institutional Review Board of Liaquat College of
A Nation-wide survey on financial impact of COVID-19 on employers of private dental practices of Pakistan

Medicine and Dentistry (IRB\# EC/36/20). The employers of the private dental clinics of Pakistan from all provinces were included in this study. Employers of the dental practices who declined to consent were excluded from the study. For sample recruitment, purposive sampling was performed. A pre-tested and validated survey form, comprising of 23 questions, was circulated through social media and email. The questionnaire was not adopted by any previous study and was designed exclusively by the Principal investigator and Co-investigators. The Pretesting of the form was executed by testing of the questionnaire via a sample of dental clinic employers from all provinces of Pakistan. For the determination of the internal consistency of the questionnaire, Cronbach Alpha was used with a value of 0.821 . the sample size was calculated by using Openepi sample size calculator version 3.01 after assuming that COVID-19 has impact on $50 \%$ Dentists of Pakistan. At 5.03\% margin of error and $95 \%$ confidence interval, the calculated sample size was 378. The questionnaire was divided into three sections. Section 1 comprised of questions about the demographic details of the participants. In Section 2, the participants were inquired about their years of experience, ownership of the practice (own property/ rental), the total number of staff including associate doctors, opening/closure status, and total working hours/day during COVID-19 lockdown. Information regarding average patient flow, revenue generated during April and May 2020, and the type of PPE provided to the staff was also obtained. In Section 3, questions were asked to assess the employers' perspective on the difficulty faced by them to provide PPE and salary to staff, and if the patients should be additionally charged for the PPE and their concerns if the lockdown restrictions last until August. Data were stored and analyzed using IBM-SPSS version 23.0, Counts with percentages were used for baseline characteristics like gender, age group, marital status, number of children, and type of earner of all studied participants, across all provinces of Pakistan. Pearson Chi-Square test of independence was used to examine the association of clinical setup with the status of ownership, PPE outcomes, and the effect of COVID -19. P-values less than 0.05 were considered statistically significant.

\section{RESULTS}

The baseline characteristics of studied samples are shown in Table-1. Three hundred and seventy-nine employers participated in this study. Out of which $47 \%$ of data were received from Sindh, 34.8\% from Punjab, $10.3 \%$ from Baluchistan, and $7.9 \%$ from KPK. Most of the respondents were male $(78.6 \%)$ and the average reported age was between 41-50 years (36.7\%). Most of the participants were married 
Sarwar H/ Qureshi NR/ Fatima S/ Naeem MM/ Inayat A

Table 1: Basic demographic characteristics of Studied Samples $(n=379)$

\begin{tabular}{|c|c|c|c|c|c|c|c|c|c|c|c|}
\hline \multirow{2}{*}{\multicolumn{2}{|c|}{ Characteristics }} & \multicolumn{10}{|c|}{ Province } \\
\hline & & \multicolumn{2}{|c|}{$\begin{array}{c}\text { Sindh } \\
(n=178)\end{array}$} & \multicolumn{2}{|c|}{$\begin{array}{c}\text { Punjab } \\
(n=132)\end{array}$} & \multicolumn{2}{|c|}{$\begin{array}{c}\text { Baluchistan } \\
(n=39)\end{array}$} & \multicolumn{2}{|c|}{$\begin{array}{c}\text { KPK } \\
(n=30)\end{array}$} & \multicolumn{2}{|c|}{$\begin{array}{c}\text { Total } \\
(n=379)\end{array}$} \\
\hline & & $n$ & $\%$ & $n$ & $\%$ & $n$ & $\%$ & $n$ & $\%$ & $n$ & $\%$ \\
\hline \multirow{2}{*}{ Gender } & Male & 141 & 79.2 & 104 & 78.8 & 28 & 71.8 & 25 & 83.3 & 298 & 78.6 \\
\hline & Female & 37 & 20.8 & 28 & 21.2 & 11 & 28.2 & 5 & 16.7 & 81 & 21.4 \\
\hline \multirow{5}{*}{ Age (Years) } & $22-30$ & 48 & 27.0 & 9 & 6.8 & 3 & 7.7 & 1 & 3.3 & 61 & 16.1 \\
\hline & $31-40$ & 59 & 33.1 & 45 & 34.1 & 12 & 30.8 & 8 & 26.7 & 124 & 32.7 \\
\hline & \begin{tabular}{|l|}
$41-50$ \\
\end{tabular} & 48 & 27.0 & 59 & 44.7 & 20 & 51.3 & 12 & 40.0 & 139 & 36.7 \\
\hline & 51-60 & 18 & 10.1 & 15 & 11.4 & 4 & 10.3 & 7 & 23.3 & 44 & 11.6 \\
\hline & 61 or older & 5 & 2.8 & 4 & 3.0 & 0 & 0.0 & 2 & 6.7 & 11 & 2.9 \\
\hline \multirow{2}{*}{$\begin{array}{l}\text { Marital } \\
\text { Status }\end{array}$} & Married & 135 & 75.8 & 121 & 91.7 & 37 & 94.9 & 28 & 93.3 & 321 & 84.7 \\
\hline & Single & 43 & 24.2 & 11 & 8.3 & 2 & 5.1 & 2 & 6.7 & 58 & 15.3 \\
\hline \multirow{5}{*}{$\begin{array}{l}\text { No. of } \\
\text { Children }\end{array}$} & 1 Child & 37 & 20.8 & 13 & 9.8 & 3 & 7.7 & 3 & 10.0 & 56 & 14.8 \\
\hline & 2 Children & 38 & 21.3 & 32 & 24.2 & 10 & 25.6 & 6 & 20.0 & 86 & 22.7 \\
\hline & 3 Children & 32 & 18.0 & 65 & 49.2 & 19 & 48.7 & 11 & 36.7 & 127 & 33.5 \\
\hline & \begin{tabular}{|l|} 
More than 3 \\
children
\end{tabular} & 23 & 12.9 & 12 & 9.1 & 6 & 15.4 & 9 & 30.0 & 50 & 13.2 \\
\hline & None & 48 & 27.0 & 10 & 7.6 & 1 & 2.6 & 1 & 3.3 & 60 & 15.8 \\
\hline \multirow{3}{*}{$\begin{array}{l}\text { Type of } \\
\text { Earner }\end{array}$} & Sole Earner & 64 & 36.0 & 69 & 52.3 & 18 & 46.2 & 14 & 46.7 & 165 & 43.5 \\
\hline & \begin{tabular}{|l|} 
Primary \\
Earner
\end{tabular} & 55 & 30.9 & 35 & 26.5 & 13 & 33.3 & 9 & 30.0 & 112 & 29.6 \\
\hline & $\begin{array}{l}\text { Secondary } \\
\text { Earner }\end{array}$ & 59 & 33.1 & 28 & 21.2 & 8 & 20.5 & 7 & 23.3 & 102 & 26.9 \\
\hline
\end{tabular}

Table 2: Association of Clinical Setup characteristics with type of ownership of the Dental Practices

\begin{tabular}{|c|c|c|c|c|c|c|}
\hline & \multicolumn{4}{|c|}{$\begin{array}{c}\text { Type of ownership of clinical Set-up } \\
\text { premises }\end{array}$} & \multirow{3}{*}{ p-value } \\
\hline & & \multicolumn{2}{|c|}{$\begin{array}{l}\text { Owned } \\
(n=186)\end{array}$} & \multicolumn{2}{|c|}{$\begin{array}{l}\text { On Rent } \\
\text { ( } n=193)\end{array}$} & \\
\hline & & $n$ & $\%$ & $\mathrm{~N}$ & $\%$ & \\
\hline \multirow{5}{*}{$\begin{array}{l}\text { Number of staff in my } \\
\text { practice }\end{array}$} & less than 3 & 33 & 17.7 & 62 & 32.1 & \multirow{5}{*}{$<0.01^{*}$} \\
\hline & 3 to 4 & 75 & 40.3 & 76 & 39.4 & \\
\hline & 5 to 7 & 38 & 20.4 & 38 & 19.7 & \\
\hline & 7 to 9 & 31 & 16.7 & 11 & 5.7 & \\
\hline & 10 or more & 9 & 4.8 & 6 & 3.1 & \\
\hline $\begin{array}{l}\text { My dental practice was } \\
\text { Open/Close with }\end{array}$ & $\begin{array}{l}\text { Open and had business } \\
\text { as usual }\end{array}$ & 2 & 1.1 & 9 & 4.7 & \multirow{4}{*}{$<0.01^{*}$} \\
\hline \multirow[t]{3}{*}{ Patient Volume } & $\begin{array}{l}\text { Open but had lower } \\
\text { patient volume than } \\
\text { usual }\end{array}$ & 98 & 52.7 & 69 & 35.8 & \\
\hline & $\begin{array}{l}\text { closed but had seen } \\
\text { emergency patients only }\end{array}$ & 67 & 36.0 & 73 & 37.8 & \\
\hline & $\begin{array}{l}\text { closed and did not see } \\
\text { any patient }\end{array}$ & 19 & 10.2 & 42 & 21.8 & \\
\hline \multirow{5}{*}{$\begin{array}{l}\text { My practice was open } \\
\text { for Duration of }\end{array}$} & 8 hours/day & 8 & 4.3 & 5 & 2.6 & \multirow{5}{*}{$<0.01^{*}$} \\
\hline & 5 to 7 hours/day & 31 & 16.7 & 16 & 8.3 & \\
\hline & 2 to 4 hours/day & 96 & 51.6 & 81 & 42.0 & \\
\hline & less than 2 hours/day & 25 & 13.4 & 34 & 17.6 & \\
\hline & It was closed & 26 & 14.0 & 57 & 29.5 & \\
\hline \multirow[t]{5}{*}{ volume of patient } & less than $5 \%$ & 94 & 50.5 & 108 & 56.0 & \multirow[t]{5}{*}{0.71} \\
\hline & $5 \%$ to $10 \%$ & 34 & 18.3 & 36 & 18.7 & \\
\hline & $11 \%$ to $24 \%$ & 26 & 14.0 & 18 & 9.3 & \\
\hline & $25 \%$ to $50 \%$ & 20 & 10.8 & 22 & 11.4 & \\
\hline & $51 \%$ to $75 \%$ & 12 & 6.2 & 9 & 4.7 & \\
\hline
\end{tabular}

$* \mathrm{p}<0.05$ was considered significant using Pearson Chi Square test

$(84.7 \%)$ and had three children $(33.5 \%) .43 .5 \%$ of the respondents were the sole earners of their families.
A Nation-wide survey on financial impact of COVID-19 on employers of private dental practices of Pakistan

Table-2 reports the association of clinical setup details with the type of ownership of dental practices. According to the results, $49.1 \%$ of participants owned their dental practice whereas, $50.9 \%$ were tenants (had their dental clinic on a rental basis). $40.3 \%$ of owners and $39.4 \%$ of the tenants reported having 3-4 staff members. $52.7 \%$ of the owners opened their practices but had less than usual patient volume; whereas, $37.8 \%$ of the tenants chose to close their practices and catered to emergency patients only on need basis. Both the owners and the tenants resumed dental clinics for 2-4 hours/day (51.6\% and $42.0 \%$ respectively). Less than $5 \%$ of the patient volume was experienced by both the owners, as well as, the tenants (50.5\% and $56 \%$ respectively). Chi-square test gives significant association for the number of staff in practice, the opening of the dental practice, and the duration of a dental practice with the type of clinical setup for dental practice $(\mathrm{p}<0.05)$.

Association of the provision of PPE to the employees with the type of ownership of clinical set-up is demonstrated in Table-3. Most of the owners (53.2\%) provided Bodysuit, N95 mask, surgical mask, Goggles, Face shield as PPE to their employees; whereas, $38.3 \%$ of the tenants provided Gown, Surgical mask, and goggles only $(\mathrm{p}=0.02)$. This association was found to be statistically significant $(\mathrm{p}<0.02)$.

Table 3: Association of provision of PPEs by employers to the type of ownership of Clinical set-up premises

\begin{tabular}{|c|c|c|c|c|c|c|}
\hline \multicolumn{2}{|l|}{ Outcomes on PPE } & \multicolumn{2}{|c|}{$\begin{array}{l}\text { Owned } \\
\text { ( } n=186)\end{array}$} & \multicolumn{2}{|c|}{$\begin{array}{l}\text { On Rent } \\
\text { (n=193) }\end{array}$} & \multirow[t]{2}{*}{ p-value } \\
\hline & & $n$ & $\%$ & $\mathbf{N}$ & $\%$ & \\
\hline \multirow{4}{*}{$\begin{array}{l}\text { PPE protocol of my } \\
\text { practice includes }\end{array}$} & $\begin{array}{l}\text { Gown, Head cover, } \\
\text { shoe cover, N95 } \\
\text { mask, Surgical mask, } \\
\text { Goggles, Face shield. }\end{array}$ & 49 & 26.3 & 58 & 30.1 & \multirow{4}{*}{$0.02^{*}$} \\
\hline & $\begin{array}{l}\text { Bodysuit, N95 mask, } \\
\text { Surgical mask, } \\
\text { Goggles, Face shield. }\end{array}$ & 99 & 53.2 & 53 & 27.5 & \\
\hline & $\begin{array}{l}\begin{array}{l}\text { Gown, Surgical mask, } \\
\text { goggles }\end{array} \\
\end{array}$ & 34 & 18.3 & 74 & 38.3 & \\
\hline & Other & 4 & 2.2 & 8 & 4.1 & \\
\hline \multirow{3}{*}{$\begin{array}{l}\text { My practice has } \\
\text { provided PPE to all } \\
\text { staff. }\end{array}$} & SA / A & 23 & 12.3 & 28 & 14.5 & \multirow{3}{*}{0.13} \\
\hline & SDA/ DA & 152 & 81.7 & 142 & 73.5 & \\
\hline & Neutral & 11 & 5.9 & 23 & 11.9 & \\
\hline \multirow{3}{*}{$\begin{array}{l}\text { It was difficult to } \\
\text { arrange PPE due to } \\
\text { its high price }\end{array}$} & SA / A & 26 & 14 & 124 & 64.3 & \multirow{3}{*}{$<0.01^{*}$} \\
\hline & SDA/ DA & 119 & 64 & 28 & 14.5 & \\
\hline & Neutral & 41 & 22 & 41 & 21.2 & \\
\hline \multirow{3}{*}{$\begin{array}{l}\text { PPE protocol cost } \\
\text { should be included } \\
\text { in the treatment } \\
\text { fee. }\end{array}$} & SA / A & 39 & 21 & 147 & 76.1 & \multirow{3}{*}{$<0.01^{*}$} \\
\hline & SDA/ DA & 131 & 70.4 & 26 & 13.5 & \\
\hline & Neutral & 16 & 8.6 & 20 & 10.4 & \\
\hline
\end{tabular}

$* \mathrm{p}<0.05$ was considered significant using Pearson Chi Square test

Both the owners (81.7\%) and the tenants of the dental clinics $(73.5 \%)$ agreed that they did not provide PPE to all the staff. Furthermore, most of the owners (64\%) disagreed that they found it difficult to arrange PPE because of high cost and $70.4 \%$ disagreed that PPE cost should be included in the patient treatment fee. On the contrary, $64.3 \%$ of tenants 
Sarwar H/ Qureshi NR/ Fatima S/ Naeem MM/ Inayat A

agreed that it was difficult to arrange PPE because of the high price and $76.1 \%$ agreed that the cost should be charged from patients. This association is also found to be statistically significant as the p-value is $<0.01$.

Table-4 reports the effect of COVID-19 on revenue generation and expenditure according to the years of established dental practices. The results revealed that $65.4 \%$

Table 4: Effect of COVID-19 on revenue generation and expenses according to the year of Clinical Dental Practice

\begin{tabular}{|c|c|c|c|c|c|c|c|c|c|c|c|c|c|c|}
\hline \multirow{2}{*}{\multicolumn{2}{|c|}{ Characteristics }} & \multicolumn{2}{|c|}{$\begin{array}{l}\text { less than } \\
1 \text { year } \\
(n=26)\end{array}$} & \multicolumn{2}{|c|}{$\begin{array}{c}1-3 \\
\text { years } \\
(n=53)\end{array}$} & \multicolumn{2}{|c|}{$\begin{array}{l}3 \text { to } 5- \\
\text { years } \\
(n=135)\end{array}$} & \multicolumn{2}{|c|}{\begin{tabular}{|c|}
$5-10$ \\
years \\
$(\mathrm{n}=68)$
\end{tabular}} & \multicolumn{2}{|c|}{$\begin{array}{l}10-15 \\
\text { years } \\
(n=41)\end{array}$} & \multicolumn{2}{|c|}{$\begin{array}{c}\text { More than } \\
15 \text { years } \\
(n=56)\end{array}$} & \multirow[t]{2}{*}{$\begin{array}{c}\mathrm{p}- \\
\text { value }\end{array}$} \\
\hline & & $n$ & $\%$ & $\mathbf{N}$ & $\%$ & $n$ & $\%$ & $n$ & $\%$ & $n$ & $\%$ & $\mathrm{~N}$ & $\%$ & \\
\hline \multirow{5}{*}{$\begin{array}{l}\text { In the month of April } \\
2020, \text { Compared to } \\
\text { what is typical at your } \\
\text { practice, the revenue } \\
\text { was }\end{array}$} & less than $5 \%$ & 17 & 65.4 & 25 & 47.2 & 79 & 58.5 & 23 & 33.8 & 10 & 24.4 & 8 & 14.3 & \multirow{5}{*}{$<0.01^{*}$} \\
\hline & 5 to $10 \%$ & 3 & 11.5 & 9 & 17.0 & 13 & 9.6 & 19 & 27.9 & 5 & 12.2 & 18 & 32.1 & \\
\hline & 11 to $24 \%$ & 5 & 19.2 & 8 & 15.1 & 23 & 17.0 & 19 & 27.9 & 14 & 34.1 & 18 & 32.1 & \\
\hline & 25 to $50 \%$ & 0 & 0.0 & 10 & 18.9 & 15 & 11.1 & \begin{tabular}{|l|l|}
6 \\
\end{tabular} & \begin{tabular}{|l|l|}
8.8 \\
\end{tabular} & 8 & 19.5 & 10 & 17.9 & \\
\hline & 51 to $75 \%$ & 1 & 3.8 & 1 & 1.9 & 5 & 1.0 & 1 & 1.5 & 4 & \begin{tabular}{|l|}
9.7 \\
\end{tabular} & 2 & 3.6 & \\
\hline \multirow{3}{*}{$\begin{array}{l}\text { Paid Salary of } \\
\text { Staff(Receptionist, } \\
\text { Dental Assistants) }\end{array}$} & \begin{tabular}{|l|} 
Paid full \\
\end{tabular} & 17 & 65.4 & 32 & 60.4 & 108 & 80.0 & 51 & 75.0 & 37 & 90.2 & 50 & 89.3 & \multirow{3}{*}{$<0.01^{*}$} \\
\hline & Paid 50\% & 3 & 11.5 & 15 & 28.3 & 20 & 14.8 & 15 & 22.1 & 1 & 2.4 & \begin{tabular}{|l|l|}
5 \\
\end{tabular} & 8.9 & \\
\hline & $\begin{array}{l}\text { Could not pay } \\
\text { at all }\end{array}$ & 6 & 23.1 & 6 & 11.3 & 7 & 5.2 & 2 & 2.9 & 3 & 7.3 & 1 & 1.8 & \\
\hline \multirow{4}{*}{$\begin{array}{l}\text { Paid Salary of } \\
\text { Employee Dentists }\end{array}$} & \begin{tabular}{|l|} 
Paid full \\
\end{tabular} & 8 & 30.8 & 27 & 51.9 & \begin{tabular}{|l|}
94 \\
\end{tabular} & 71.2 & 36 & 57.1 & 28 & 70.0 & 35 & 67.3 & \multirow{4}{*}{$<0.01^{*}$} \\
\hline & Paid 50\% & 6 & 23.1 & 12 & 23.1 & 25 & 18.9 & 14 & 22.2 & 1 & 2.5 & \begin{tabular}{|l|l|}
5 \\
\end{tabular} & 9.6 & \\
\hline & $\begin{array}{l}\text { Could not pay } \\
\text { at all }\end{array}$ & 7 & 26.9 & 8 & 15.4 & 5 & 3.8 & 2 & 3.2 & 5 & 12.5 & 6 & 11.5 & \\
\hline & $\begin{array}{l}\text { Paid only the } \\
\text { percentage of } \\
\text { the work they } \\
\text { did }\end{array}$ & 5 & 19.2 & 5 & 9.6 & 8 & 6.1 & 11 & 17.5 & 6 & 15.0 & 6 & 11.5 & \\
\hline \multirow{3}{*}{$\begin{array}{l}\text { For the month of May } \\
2020 \text {, my practice is }\end{array}$} & \begin{tabular}{|l|} 
Open and \\
offering all \\
procedures
\end{tabular} & 6 & 23.1 & 12 & 22.6 & 16 & 11.9 & 13 & 19.1 & 12 & 29.3 & 8 & 14.3 & \multirow{3}{*}{$<0.01^{*}$} \\
\hline & $\begin{array}{l}\text { Open and } \\
\text { seeing } \\
\text { emergency } \\
\text { patients only }\end{array}$ & 11 & 42.3 & 31 & 58.5 & 106 & 78.5 & 41 & 60.3 & 24 & 58.5 & 40 & 71.4 & \\
\hline & $\begin{array}{l}\text { closed and not } \\
\text { seeing any } \\
\text { patients }\end{array}$ & 9 & 34.6 & 10 & 18.9 & 13 & 9.6 & 14 & 20.6 & 5 & 12.2 & 8 & 14.3 & \\
\hline
\end{tabular}

$* \mathrm{p}<0.05$ was considered significant using Pearson Chi Square test

of employers with less than one year of practice, $47.2 \%$ of those with 1-3 years of practice, $58.5 \%$ with the practice of 3-5 years and $33.8 \%$ of employers with 5-10 years of established clinical set-ups reported that $<5 \%$ of revenue was generated in April. On the contrary, $34.1 \%$ of employers with 10-15 years of practice and $32.1 \%$ of those with established set-up for more than 15 years reported the average revenue generated during April was 11-24\% and 5-24\%, respectively. The Chi-square test shows a statistically significant association between all the groups $(\mathrm{p}<0.01)$. Most of the employers, regardless of the year of experience, paid full salaries to their staff and employee dentists during April $(p<0.01)$. Most dental clinics remained open and catered to emergency patients only during May. A statistically significant association between the employers of different years of clinical set-up was reported as the p-value was found to be less than 0.01 .

Table -5 demonstrates the future strategies planned by employers with regards to years of practice if the lock-down lasts until the end of August. According to the results, 40.8\% of employers with less than 10 years of practice had planned to adjust the salaries of staff in the future and $23.4 \%$ planned
A Nation-wide survey on financial impact of COVID-19 on employers of private dental practices of Pakistan

Table 5: Future strategies planned by employers with different years of experience if the current situation lasts until August

\begin{tabular}{|c|c|c|c|c|c|}
\hline \multirow{3}{*}{$\begin{array}{l}\text { If current restrictions last } \\
\text { until End of August 2020, } \\
\text { I will }\end{array}$} & \multicolumn{4}{|c|}{ Years of Practice } & \multirow{3}{*}{ p-value } \\
\hline & \multicolumn{2}{|c|}{$\begin{array}{c}<=10 \text { years } \\
(n=282)\end{array}$} & \multicolumn{2}{|c|}{$\begin{array}{c}>10-\text { years } \\
(n=97)\end{array}$} & \\
\hline & $n$ & $\%$ & $\mathbf{N}$ & $\%$ & \\
\hline $\begin{array}{l}\text { Find innovative ways to } \\
\text { expand my patient base }\end{array}$ & 66 & 23.4 & 28 & 28.9 & \\
\hline $\begin{array}{l}\text { Find innovative ways to } \\
\text { lower my operating } \\
\text { costs }\end{array}$ & 50 & 17.7 & 32 & 33.0 & \\
\hline $\begin{array}{l}\text { Borrow money to } \\
\text { address financing } \\
\text { shortfalls }\end{array}$ & 17 & 6.0 & 7 & 7.2 & $<0.01^{*}$ \\
\hline $\begin{array}{l}\text { Adjust staffing or } \\
\text { salaries of my staff }\end{array}$ & 115 & 40.8 & 16 & 16.5 & \\
\hline $\begin{array}{l}\text { I do not think I can } \\
\text { sustain my practice }\end{array}$ & 34 & 12.1 & 14 & 14.4 & \\
\hline
\end{tabular}

${ }^{*} \mathrm{p}<0.05$ was considered significant using Pearson Chi Square test

to find innovative ways to expand their patient base. On the contrary, $33 \%$ of employers with more than 10 years of practice planned to find innovative ways to lower their operating costs, and $28.9 \%$ planned to find innovative ways to expand the patient base. Pearson Chi-Square test gives a significant association between years of practice and future planning by employers with $\mathrm{p}<0.01$.

\section{DISCUSSION}

The whole world is struggling to conform to the changing dynamics after the outbreak of the pandemic, and the global dental industry too bore no exemption in this regard. The COVID-19 pandemic has forced the dental industry around the world to modify the standard operating procedures and to provide emergency dental care only. The moral and ethical obligation to the patient and dental staff safety guided the global dental industry to limit the practices and abide by the laws of lockdowns. Amidst the time of such unexampled turmoil, the global dental community has endured both psychological and economic impacts. ${ }^{11}$ The current study is the first nationwide survey conducted to assess the financial impact of COVID-19 lockdown on employers of dental setups throughout Pakistan. The objective of our survey was to exclusively highlight the pecuniary difficulties and pressures faced by private dental practice employers with regards to COVID-19 crises, and to the concerned economical and health regulatory bodies of the region.

The results of this cross-sectional study revealed that most of the respondents were males, married, and had three children on average. Similar results were reported in a study conducted among the dental practitioners of the UK where $70.4 \%$ were males, $80.9 \%$ were married and $47.1 \%$ had three children. ${ }^{12}$ In the present study, most of the participants were the sole earners of their families corroborating with 
Sarwar H/ Qureshi NR/ Fatima S/ Naeem MM/ Inayat A

the results of another study conducted in New Zealand reporting $63.5 \%$ dentists as principal earners in the family. ${ }^{13}$ The resulted stats signify the higher level and extent of liability endured by the dental employers of private practices for not only supporting their families but also being equally responsible for the personal and professional financial expenditures.

Our study revealed that the strength of dental clinic tenants equals the existence/strength of dental clinic owners. The COVID-19 period rendered clear visibility of the walkin patients' frequency, in comparison to the pre-COVID-19 period, which evidently was lower, even though private clinics (fully owned) remained open. The tenants on the other hand by choice closed their respective practices; however, they did cater to the emergency cases. American Dental Association reported that $75 \%$ of the dental practices are seeing only emergencies and the rest are completely closed..$^{14}$ A survey by the Irish Dental Association conducted on 369 dentists reported a similar finding in which $52 \%$ confined to emergency treatments only, whilst $18 \%$ completely closed their practices, coupled with $83 \%$, which made changes in practicing hours. ${ }^{15}$ According to a survey conducted by Tada $\mathrm{H}$ et al., on 180 dental clinics in Hyogo, Japan, $46.7 \%$ reported a decrease in the number of patients, corroborating to the results of our study. ${ }^{16}$ Likewise, the British Dental Association also reported less than 25\% of patient turnover than usual due to the suspended routine dental care.$^{17}$ In a Polish cross-sectional study, Tysiac et al., reported that $71.2 \%$ of dentists suspended their dental practice and subsequently observed an evident decrease in the number of patients, after the COVID-19 outbreak. The authors associate the main reason for voluntarily suspension of dental clinics to mainly the shortage of PPE. ${ }^{18}$ Similar findings were reported by Irish Dental Association that 70\% of dentists did not have access to gowns and $30 \%$ of dentists did not have unimpeded access to masks. ${ }^{19}$ Due to the increase in demand of PPEs and disinfectants for the healthcare providers, bearing the apparent utilization of the aforementioned items for the protection of patients and staff, not only have these become scant but rather expensive, as well. A recent report estimated a $1000 \%$ increase in PPE cost compared with preCOVID-19 times..$^{20}$ Our study indicated that the tenant dental practitioners faced difficulty in providing PPE to staff because of high cost, corroborating to the results of an Iranian study. ${ }^{21}$ The owners on the other hand provided N95 masks, bodysuits, and face shields in addition to surgical masks, gowns, and goggles to their associate doctors. In a time when practices have experienced unprecedented declines in revenue, the rising cost of PPE has exacerbated the financial burden. This has forced practices to close or implement staff layoffs as indicated by the results of the present study. Moraes et al.
A Nation-wide survey on financial impact of COVID-19 on employers of private dental practices of Pakistan

revealed that the status of the Brazilian dentists got affected by $94 \%$, and $84 \%$ impact on routinely practices was observed with an increased expenditure induced due to COVID-19 PPE practices and patient screening practices. ${ }^{22}$ An Indian study reported that the patients were charged additionally for PPE. ${ }^{23}$

Although, in our study, most of the tenants agreed that the cost of PPE should be included in patients' treatment fees, yet charging patients an infection control fee may result in unethical custom. Induction of PPE cost in the aforementioned patient fee may have a significant impact on accessing care, especially for patients of a lower socioeconomic status. As suggested by Muzumdar et al, a more ethical and feasible approach would be to advocate for higher insurance reimbursement or coverage, or both, of appropriate Healthcare Common Procedure Coding System. This will enable the authorities to account for the increased cost of infection control, rather than charging the patients an infection control fee. ${ }^{24}$

Rather crippling losses were reported by the employers of private dental practices across Pakistan. This economical downfall of the dental industry is evident globally. ${ }^{1725}$ According to the American Dental Association, 7.9\% of net revenue was generated during the lock-down period. ${ }^{14}$ The Irish Dental Association reported 76\% dentists experienced financial loss, and about $70 \%$ amid the COVID19 outbreak. Half expect income to drop 90-100\%. ${ }^{19}$ In the present study, most of the dental practice employers paid full salaries to their staff corroborating supporting the results of a cross-sectional study conducted in Iran. ${ }^{21}$ On the contrary, a US-based survey involving twenty thousand dentists reflected that only $27 \%$ paid the full salary to staff, whereas, $45 \%$ paid half the salary, and $28 \%$ did not pay at all. $^{26}$

If this situation persists till the end of August, Pakistani dental employers, who bear less than 10 years of practice have planned to compensate for the financial crises by adjusting their staff salaries. On the other hand, dental employers with more than 10 years of clinical practice seemed more financially stable and planned to find innovative ways to lower their treatment costs. These results are in agreement with an Indian study concluding that the practitioners with less than 10 years of experience may face more hardships than those with more than 10 years of experience. $^{27}$

Economists have painted a rather bleak picture for the world economy, as they foresee a downturn in the global economy, which, as predicted by them will lead to a worldwide recession in the long term. The Governments of many developed countries with high-income average have understood the gravity of this situation and have extended 
Sarwar H/ Qureshi NR/ Fatima S/ Naeem MM/ Inayat A

support to the dental practices. Numerous favorable financial plans have been laid by such governments. For instance, the government of the UK is ready to support the business owners by lending loans or credit, if they are facing difficulties in the payment of supplies or salaries to the staff. ${ }^{28}$ The dental practices of NHS, UK will receive funds to reimburse the losses due to the COVID-19 outbreak. ${ }^{17}$ The Canadian Government announced support of \$27 billion, where the dentists can also apply for this support. ${ }^{29}$ According to IDA, the Irish Government will provide COVID-19 business load ranging from $€ 5000$ to $€ 50000$ and the owners of dental practices can also apply for these loans. ${ }^{1530}$ St. Claire HealthCare in Morehead, Kentucky, USA has recently issued a statement in which they have mentioned that they are laying off a quarter of their staff temporarily, who are not directly involved in the care of patients with COVID-19. ${ }^{31}$ The Ministry of National Health Services, Regulation and Coordination, Pakistan has provided the guidelines for dentists and dental patients' management during COVID1-19 pandemic on May 3rd 2020 32 , but the government and the dental regulatory bodies have not yet set-up any economic response plan to support the local dental community, experiencing a major economic downfall. This research may assist the policymakers in preparing appropriate countermeasures during and after the COVID-19 pandemic.

\section{CONCLUSION}

The COVID-19 has immensely affected the financial stature and prospects of dentists in Pakistan. The extremely low patient frequency and revenue generation have posed rather substantial challenges for the dental clinic owners. The challenges primarily comprise the swift provision of PPEs, their costs, staff salaries, and other pertinent expenses. The owners and the practitioners with more than 10 years of practice were more financially stable and were able to manage the unforeseen circumstances. However, the tenant dentist employers and those who are new in this discipline have faced challenges in managing their expenses. The study affirmed that dentists are integrating PPE practices to cope with the current COVID-19 scenario. They are uncertain about the future and the incertitude that comes with their ability to pay their staff. It is, therefore, highly recommended that competent authorities from these countries should step up and support dental practices, which are on the brink of closure due to financial losses being endured by them due to the COVID-19 pandemic.

\section{CONFLICT OF INTEREST}

None to declare
A Nation-wide survey on financial impact of COVID-19 on employers of private dental practices of Pakistan

\section{REFERENCES}

1. Cucinotta D, Vanelli M. WHO declares COVID-19 a pandemic. Acta bio-medica Atenei Parm. 2020;91:157-160.

2. Gavi. What is COVID-19 and how does it spread? Published 2020. https://www.gavi.org/vaccineswork/what-is-COVID-19-and-how-doesit-spread

3. McKee M, Stuckler D. If the world fails to protect the economy, COVID-19 will damage health not just now but also in the future. Nat Med. 2020;26:640-642.

https://doi.org/10.1038/s41591-020-0863-y

4. Ozili PK, Arun T. Spillover of COVID-19: impact on the Global Economy. Available SSRN 3562570. Published online 2020. https://doi.org/10.2139/ssrn.3562570

5. Ofori-Attah S. Dentistry, and why it is a great career. Br Dent J. 2017;223:81-84.

https://doi.org/10.1038/sj.bdj.2017.617

6. Times. TN. The workers who face the greatest coronavirus risk. 20 MAR 2020.

https://www.nytimes.com/interactive/2020/03/15/business/economy/ coronavirus-worker-risk.html.

7. Meng L, Hua F, Bian Z. Coronavirus disease 2019 (COVID-19): emerging and future challenges for dental and oral medicine. J Dent Res. 2020;99:481-487.

https://doi.org/10.1177/0022034520914246

8. American Dental Association. ADA calls upon dentists to Postpone elective procedures. Published 2020.

https://www.ada.org/en/press-room/news-releases $/ 2020$ archives/march/ada-calls-upon-dentists-to-postpone-electiveprocedures)

9. CORONA VIRUS: standard operating procedures for primary care settings.

10. Consolo U, Bellini P, Bencivenni D, Iani C, Checchi V. Epidemiological Aspects and Psychological Reactions to COVID-19 of Dental Practitioners in the Northern Italy Districts of Modena and Reggio Emilia. Int J Environ Res Public Health. 2020;17:3459. https://doi.org/10.3390/ijerph17103459

11. Imran F, Saqib A. COVID-19 outbreak and its monetary implications for dental practices, hospitals and healthcare workers. https//pmj bmj com/content/postgradmedj/early/2020/04/03/ postgradmedj-2020-137781 full pdf. Published online 2020. https://doi.org/10.1136/postgradmedj-2020-137781

12. Myers HL, Myers LB. "It's difficult being a dentist": stress and health in the general dental practitioner. Br Dent J. 2004;197:89-93. https://doi.org/10.1038/sj.bdj.4811476

13. Ayers KMS, Thomson WM, Rich AM, Newton JT. Gender differences in dentists' working practices and job satisfaction. J Dent. 


\section{Sarwar H/ Qureshi NR/ Fatima S/} Naeem MM/ Inayat A

2008;36:343-350.

https://doi.org/10.1016/j.jdent.2008.01.012

14. Nasseh K, Vujicic M. Modeling the impact of COVID-19 on US dental spending. Heal Policy Inst Res Brief Am Dent Assoc April. Published online 2020.

15. IDA News. COVID-19 business and employment supports available. Available: http://irishdentalassociation.newsweaver.com/ newsletter/40uglfzc4qylcys22xtzj2? $a=1 \& p=56657247 \& t=22322575$ [Accessed 21 Mar 2020].

16. Tada H, Shao W, Ishimaru N, Kudo Y. The life in Japan and status of private dental office at the times of COVID-19. Oral Dis. Published online 2020.

https://doi.org/10.1111/odi.13449

17. BDA. Live updates: coronavirus and dentistry. Available: https://bda.org/advice/Coronavirus/Pages/latest-updates.aspx [Accessed 21 Mar 2020].

18. Tysiac-Mista M, Dziedzic A. The Attitudes and Professional Approaches of Dental Practitioners during the COVID-19 Outbreak in Poland: A Cross-Sectional Survey. Int J Environ Res Public Health. 2020;17(13):4703.

https://doi.org/10.3390/ijerph17134703

19. IDA News. Scale of dental collapse highlighted in survey. Available: http://irishdentalassociation.newsweaver.com/newsletter/13ctcsav $7 c$ z1cys22xtzj2? $a=1 \& p=56657247 \& t=22322575$ [Accessed $21 \mathrm{Mar}$ 2020].

20. Zimmet M, Silverberg J, Stawis A, Greenfield M. Society for Healthcare Organization Procurement Professionals. 2020. Available at: http://cdn.cnn.com/cnn/2020/images/04/16/shopp.covid. ppd.costs.analysis_.pdf. Accessed May 24, 2020.

21. Ahmadi H, Ebrahimi A, Ghorbani F. The Impact of COVID-19 Pandemic on Dental Practice: A Questionnaire-Based Report. Published online 2020.

https://doi.org/10.21203/rs.3.rs-38321/v1

22. Moraes RR, Correa MB, Queiroz AB, Daneris A, Lopes JP, PereiraCenci T, D'Avila OP, Cenci MS, Lima GS, Demarco FF. COVID-19 challenges to dentistry in the new pandemic epicenter: Brazil. medRxiv. 2020 Jan 1.

https://doi.org/10.1101/2020.06.11.20128744
A Nation-wide survey on financial impact of COVID-19 on employers of private dental practices of Pakistan

23. Prasad A, Parakh MK. Coronavirus and Its Impact on Dental Fraternity. J Heal Allied Sci NU. Published online 2020. https://doi.org/10.1055/s-0040-1713835

24. Muzumdar S, Grant-Kels JM, Feng H. The ethics of charging patients an infection control fee in the context of COVID-19. J Am Acad Dermatol. 2020;83:981-82.

https://doi.org/10.1016/j.jaad.2020.06.040

25. Schwendicke F, Krois J, Gomez J. Impact of SARS-CoV2 (COVID-19) on dental practices: Economic analysis. J Dent. Published online 2020:103387.

https://doi.org/10.1016/j.jdent.2020.103387

26. ADA News. HPI poll examines impact of COVID-19 on dental practices.

https://www.ada.org/en/publications/ada-news/2020-archive/april/hpipoll-examines-impact-of-covid-19-on-dental-practices .[Accessed:14 April 2020]. Published on 01 April 2020.

27. Singh Kochhar A, Singh G. Financial Aspect of COVID-19 on Orthodontic Practice in India. J Indian Orthod Soc. Published online 2020:0301574220930173.

https://doi.org/10.1177/0301574220930173

28. Dentistry. Coronavirus - what's the financial impact on dentistry? Available: https://www.dentistry.co.uk/2020/03/19/coronavirusfinancial-impact-dentistry/[Accessed 21 Mar 2020].

29. Department of Finance Canada . Canada's COVID-19 Economic Response Plan: Support for Canadians and Businesses. Available: https://www.canada.ca/en/department-finance/news/2020/03/canadascovid-19-economic-response-plan-support-for-canadians-andbusinesses.

30. COVID-19 business loan. Available:

https://microfinanceireland.ie/loan-packages/covid19/[Accessed 21 Mar 2020].

31. Herald Leader. Morehead Hospital furloughs 300 staff amid COVID-19 outbreak for lack of revenue, 2020. Available: https://www.kentucky.com/news/coronavirus/article241524521.html.

32. Ministry of Health Pakistan. Guidelines for Providing Dental Care Services durig COVID-19.

http://www.nhsrc.gov.pk/SiteImage/Misc/files/Dental-Services.pdf 